\title{
Pemodelan Tingkat Konsumsi Ikan di Jawa Timur Menggunakan Pendekatan Regresi Nonparametrik Spline
}

\author{
Dias Setya Ptayogo, Wiwiek Setya Winahju dan Pratnya Paramita Oktaviana \\ Departemen Statistika, Fakultas Matematika, Komputasi dan Sains Data \\ Institut Teknologi Sepuluh Nopember (ITS) \\ e-mail: pramitha.oktaviana@gmail.com
}

\begin{abstract}
Abstrak-Indonesia merupakan negara maritim dan merupa-kan perairan yang cukup luas. Potensi yang cukup luas terdapat di laut Indonesia, sektor perikanan memiliki peluang yang cukup besar dan berkembang. Namun penduduk Indonesia memiliki tingkat konsumsi ikan yang masih rendah di bandingkan dengan negara-negara tetangga. Mengutip data Kementrian Kelautan dan Perikanan (KKP) pertumbuhan konsumsi ikan tahun 20102014 Jawa Timur memiliki pertumbuhan diatas $10 \%$ sebesar $10,12 \%$. Dalam kaitannya dengan tingkat konsumsi ikan yang masih rendah untuk Indonesia khususnya di daerah Jawa Timur, maka salah satu hal yang dapat dilakukan adalah apa faktorfaktor yang berkaitan dengan tingkat konsumsi ikan di Jawa Timur masih rendah. Sehingga pada penelitian kali ini akan digunakan salah satunya adalah menggunakan pendekatan regresi nonparametrik spline untuk melihat pemodelan tingkat konsumsi ikan di Jawa Timur tahun 2016. Hasil dari penelitian ini didapatkan bahwa seluruh variabel prediktor berpengaruh signifikan dan semua asumsi telah terpenuhi. Model regresi nonparametrik spline terbaik adalah spline dengan kombinasi knot. Model ini memiliki nilai koefisisen determisani sebesar $85,61 \%$
\end{abstract}

Kata Kunci-Kementrian Kelautan dan Perikanan, Tingkat Konsumsi Ikan, dan Regresi Nonparametrik Spline.

\section{PENDAHULUAN}

$\mathbf{I}_{w}^{\mathrm{N}}$ NDONESIA merupakan negara maritim dan sebagian wilayah-nya merupakan perairan yang cukup luas. Indonesia merupa-kan negara yang kaya akan sumber daya alam khususnya sum-ber daya perairan. Potensi yang cukup luas terdapat di laut In-donesia. Sektor perikanan memiliki peluang yang cukup besar untuk dapat berkembang. Seharusnya dapat memanfaatkan ke-kayaan alamnya secara maksimal, termasuk banyak jenis ikan baik untuk dikonsumsi penduduk dan tentunya dapat meme-nuhi kebutuhan protein. Namun, penduduk Indonesia memiliki tingkat konsumsi ikan yang masih rendah, dengan nilai tingkat konsumsi ikan sebesar 41 kilogram per kapita per tahun. Ren-dahnya konsumsi ikan per kapita penduduk di Indonesia ber-banding terbalik dengan wilayah yang kaya akan sumber pro-tein hewani ini..

Konsumsi makanan merupakan salah satu faktor yang secara langsung berpengaruh terhadap status gizi seseorang, keluarga dan masyarakat. Rendahnya konsumsi pangan atau kurang seimbangnya masukan zat-zat gizi dari makanan yang dikonsumsi mengakibatkan terlambatnya pertumbuhan oranga dan jaringan tubuh, hal ini tentunya akan mempengaruhi kualitas sumber daya manusia di masa yang akan datang. Salah satu alternatif untuk memenuhi kebutuhan akan sumber protein hewani adalah ikan. Kandungan protein ikan tidak kalah dengan kandungan protein yang berasal dari daging atau telur. Selain itu ikan adalah salah satu sumber protein hewani yang harganya lebih murah. Dengan demikian sangat beralasan bila kita mendukung program pemerintah gerakan makan ikan.

Dalam kaitannya dengan tingkat konsumsi ikan yang masih rendah untuk Indonesia khususnya di daerah Jawa Timur, maka salah satu hal yang dapat dilakukan adalah apa faktor-faktor yang berkaitan dengan tingkat konsumsi ikan di Jawa Timur masih rendah. Sehingga pada penelitian kali ini akan digunakan salah satunya adalah menggunakan pendekatan regresi. Ada tiga pendekatan untuk menganalisis kurva regresi yaitu parametrik, nonparametrik dan semiparametrik. Regresi dengan pendekatan nonparametrik merupakan metode yang dapat digunakan apabila pola data yang terbentuk tak diketahui bentuk kurva regresinya atau tidak terdapat informasi masa lalu yang lengkap tentang bentuk pola data [1].

Terdapat beberapa penelitian yang telah dilakukan sebelumnya berkaitan dengan tingkat konsumsi ikan, [2] mengenai faktor-faktor yang berhubungan dengan konsumsi ikan dan status gizi anak 1-2 tahun di Kecamatan Gandus Kota Palembang tahun 2005. Dengan hasil bahwa faktor-faktor yang berhubungan dengan konsumsi ikan anak 1-2 tahun adalah prefensi anak terhadap ikan, sedangkan status sosial ekonomi keluarga dan pendididkan ibu tidak berhubungan dengan konsumsi ikan.

Berdasarkan penjelasan sebelumnya, maka akan dilakukan penelitian dengan pemodelan tingkat konsumsi ikan di Jawa Timur menggunakan pendekatan regresi nonparametrik spline. Dengan masalah yang akan diambil yaitu dengan mengetahui faktor-faktor yang diduga mempengaruhi tingkat konsumsi ikan sehingga dalam penelitian ini dilakukan pemodelan menggunakan pendekatan regresi nonparametri spline. Dari permasalahan yang telah diuraikan ada tujuan yang ingin dicapai antara lain mendeskripsikan dan memodelkan dari kasus tingkat konsumsi ikan di Jawa Timur, utnuk memperoleh manfaat dapat memberikan informasi mengenai karakteristik data dan dapat dilakukan beberapa upaya untuk meningkatkan konsumsi ikan dari model yang dihasilkan. 


\section{TINJAUAN PUSTAKA}

\section{A. Regresi Nonparametrik Spline}

Regresi nonparametrik adalah suatu metode statistika yang digunakan untuk mengetahui adanya pola hubungan antara variabel respon dengan variabel prediktor yang tidak diketahui bentuk fungsinya. Kurva regresi dalam regresi nonparametrik diasumsikan smooth (mulus) yang berarti termuat dalam suatu ruang fungsi tertentu, sehingga regresi nonparametrik memiliki flesksibilitas yang tinggi [1].

Salah satu model regresi nonparametrik yang memiliki interpretasi statistik dan visual yang sangat khusus dan sangat baik adalah spline. Spline merupakan potongan polinomial yang mempunyai sifat khusus pada setiap interval kurva, sehingga memungkinkan untuk menyesuaikan diri secara efektif terhadap karakteristik lokal dari fungksi atau data. Regresi nonparametrik spline yang terdiri dari variabel respon dan satu variabel prediktor disebut regresi nonparametrik spline univariabel [3]. Jika kurfa regresi didekati dengan fungsi spline, maka diperoleh model regresi

$$
\begin{array}{r}
f\left(x_{j i}\right)=\sum_{q=0}^{l} \beta_{q j} x_{j i}^{q}+\sum_{g=1}^{m} \beta_{(l+g) j}\left(x_{j i}-t_{g j}\right)_{+}^{l} \\
\hat{y}=\sum_{q=0}^{l} \beta_{q j} x_{j i}^{q}+\sum_{g=1}^{m} \beta_{(l+g) j}\left(x_{j i}-t_{g j}\right)_{+}^{l} \\
\text { dengan }\left(x_{j i}-t_{g j}\right)_{+}^{l}=\left\{\begin{array}{c}
\left(x-t_{g}\right)^{l}, x_{j i} \geq t_{g j} \\
0, x_{j i}<t_{g j}
\end{array}\right.
\end{array}
$$

$t_{11}, t_{12}, \ldots, t_{g j}$ merupakan titik-titik knot yang memperlihatkan pola perubahan perilaku pada fungsi pada sub-sub interval yang berbeda, sedangkan $l$ adalah derajat polinomial dan banyaknya knot dinotasikan dengan huruf $m$ [1].

Penaksiran parameter untuk regresi nonparametrik spline menggunakan metode OLS dari model (1) untuk $m$ titik knot didapatkan dalam bentuk matriks sebagai berikut.

$$
\begin{gathered}
{\left[\begin{array}{c}
y_{1} \\
y_{2} \\
\vdots \\
y_{n}
\end{array}\right]_{1 \times n}=\left[\begin{array}{ccccccc}
1 & x_{11} & \ldots & x_{k 1} & \left(x_{11}-t_{1 k}\right)_{+} & \ldots & \left(x_{j 1}-t_{m k}\right)_{+} \\
1 & x_{12} & \ldots & x_{k 2} & \left(x_{12}-t_{1 k}\right)_{+} & \ldots & \left(x_{j 2}-t_{m k}\right)_{+} \\
\vdots & \vdots & \vdots & \vdots & \vdots & \vdots & \vdots \\
1 & x_{1 n} & \ldots & x_{k n} & \left(x_{1 n}-t_{1 k}\right)_{+} & \ldots & \left(x_{j n}-t_{m k}\right)_{+}
\end{array}\right]_{(l+m) k \times n}\left[\begin{array}{c}
\beta_{0} \\
\beta_{11} \\
\vdots \\
\beta_{(l+m) k}
\end{array}\right]_{1 \times(l+m) k}+\left[\begin{array}{c}
\varepsilon_{1} \\
\varepsilon_{2} \\
\vdots \\
\varepsilon_{n}
\end{array}\right]_{1 \times n}} \\
\mathbf{y}=\mathbf{X \beta}+\boldsymbol{\varepsilon} \\
\boldsymbol{\varepsilon}
\end{gathered}
$$

dengan menggunakan metode Ordinary Least Square (OLS) yaitu metode untuk mendapatkan estimator dengan meminimumkan jumlah kuadrat error, jumlah kuadrat error diberikan oleh

$$
\begin{gathered}
\boldsymbol{\varepsilon}^{\prime} \boldsymbol{\varepsilon}=(\mathbf{y}-\mathbf{X} \boldsymbol{\beta})^{\prime}(\mathbf{y}-\mathbf{X} \boldsymbol{\beta}) \\
=\mathbf{y}^{\prime} \mathbf{y}-\mathbf{2} \boldsymbol{\beta}^{\prime} \mathbf{X}^{\prime} \mathbf{y}+\boldsymbol{\beta}^{\prime} \mathbf{X}^{\prime} \mathbf{X} \boldsymbol{\beta} \\
\frac{\partial \varepsilon^{\prime} \varepsilon}{\partial \beta}=-2 \boldsymbol{\beta}^{\prime} \mathbf{X}^{\prime} \mathbf{y}+\boldsymbol{\beta}^{\prime} \mathbf{X}^{\prime} \mathbf{X} \boldsymbol{\beta} \\
\hat{\boldsymbol{\beta}}=\left(\mathbf{X}^{\prime} \mathbf{X}\right)^{-1} \mathbf{X}^{\prime} \mathbf{y}
\end{gathered}
$$

maka estimator $\hat{\boldsymbol{\beta}}$ mempunyai variansi terkecil dapat di ketahui yaitu.

$$
\begin{aligned}
\operatorname{var}(\beta) & =\operatorname{var}\left(\left(\mathbf{X}^{\prime} \mathbf{X}\right)^{-1} \mathbf{X}^{\prime} \mathbf{y}\right) \\
& =\left(\mathbf{X}^{\prime} \mathbf{X}\right)^{-1} \mathbf{X}^{\prime} \operatorname{var}(\mathbf{y})\left(\left(\mathbf{X}^{\prime} \mathbf{X}\right)^{-1} \mathbf{X}^{\prime} \mathbf{y}\right)^{\prime} \\
& =\left(\mathbf{X}^{\prime} \mathbf{X}\right)^{-1} \mathbf{X}^{\prime} \sigma^{2} \mathbf{X}\left(\mathbf{X}^{\prime} \mathbf{X}\right)^{-1} \\
& =\sigma^{2}\left(\mathbf{X}^{\prime} \mathbf{X}\right)^{-1}
\end{aligned}
$$

Pemilihan titik knot optimal pada regresi nonparametrik spline sangatlah penting. Untuk menentukan banyaknya knot optimal digunakan kriteria adalah Generalized Cross Validation (GCV). Model spline terbaik memiliki knot optimal diperoleh dari nilai GCV yang minimum.

$$
\operatorname{GCV}\left(t_{i}, t_{2}, \ldots, t_{j}\right)=\frac{\operatorname{MSE}\left(t_{i}, t_{2}, \ldots, t_{j}\right)}{\left(n^{-1} \operatorname{trace}\left[I-A\left(t_{i}, t_{2}, \ldots, t_{j}\right)\right]\right)^{2}}
$$

dengan

$$
\operatorname{MSE}\left(t_{i}, t_{2}, \ldots, t_{j}\right)=n^{-1} \sum_{i=1}^{n}\left(y_{i}-\hat{f}\left(x_{i}\right)\right)^{2}
$$

dimana matriks $A\left(t_{i}, t_{2}, \ldots, t_{j}\right)$ diperoleh dari persamaan $\hat{y}=A\left(t_{i}, t_{2}, \ldots, t_{j}\right) y[1]$.

Pengujian serentak dilakukan untuk mengetahui signifikansi parameter model regresi secara bersama-sama seluruh variabel respon. Dengan hipotesis sebagai berikut.

$\mathrm{H}_{0}: \beta_{11}=\beta_{12}=\ldots=\beta_{(l+m) k}=0$

$\mathrm{H}_{1}$ : minimal terdapat satu $\beta_{h j} \neq 0, h=1,2, \ldots,(l+m) j=1,2, \ldots, k$ dengan statistik uji dalam pengujian serentak sebagai berikut.

$$
F_{\text {hitung }}=\frac{M S R}{M S E}
$$

Pengujian parameter model secara serentak dapat disajikan menggunakan Analysis of Variance (ANOVA) yang disajikan dalam Tabel 1 sebagai berikut

Tabel 1. ANOVA Model Regresi

\begin{tabular}{ccccc}
\hline \hline $\begin{array}{c}\text { Sumber } \\
\text { Variasi }\end{array}$ & Df & SS & MS & F hitung \\
\hline Regresi & $k(l+m)$ & $S S R$ & $M S R=\frac{S S R}{k(l+m)}$ & \\
Residual & $n-k(l+m)-1$ & $S S E$ & $M S E=\frac{S S E}{n-k(l+m)-1}$ & $F_{\text {hitumg }}=\frac{M S R}{M S E}$ \\
Total & $n-1$ & $S S T$ & & \\
\hline \hline
\end{tabular}

tolak $\mathrm{H}_{0}$ jika $F_{\text {hitung }}>F_{\alpha ; \text { dbregresi;dberror }}$ yang berarti minimal terdapat satu variabel prediktor yang berpengaruh signifikan terhadap variabel respon. Salah satu kriteria yang digunakan untuk mengukur kebaikan dari model adalah menggunakan $R^{2}$ dan $R^{2}-A d j[4]$

$$
R^{2}=\frac{S S R}{S S T} \times 100 \% \quad R^{2}-A d j=1-\frac{M S E}{M S T} \times 100 \%
$$

Pengujian signifikan parameter secara parsial ini bertujuan untuk melihat signifikansi yang berpengaruh setiap variabel prediktor terhadap variabel respon secara parsial. Pengujian ini menggunakan uji $t$ dengan hipotesis sebagai berikut.

$\mathrm{H}_{0}: \beta_{h j}=0$

$\mathrm{H}_{1}: \beta_{h j} \neq 0 \quad, h=1,2, \ldots,(l+m), j=1,2, \ldots, k$ 
Statistik uji : $\quad t_{\text {hitung }}=\frac{\hat{\beta}_{h j}}{\operatorname{s.e}\left(\hat{\beta}_{h j}\right)}$

Daerah kritis : tolak $\mathrm{H}_{0}$ jika $\left|t_{\text {hitung }}\right|>t_{(\alpha / 2 ; n-k(l+m)-1)}$ dengan s.e $\left(\hat{\beta}_{k j}\right)=\sqrt{\operatorname{var}\left(b_{k j}\right)}$ dimana $\operatorname{var}\left(b_{k j}\right)=\left(\mathbf{X}^{\prime} \mathbf{X}\right)^{-1}$ MSE [4]

\section{B. Tingkat Konsumsi Ikan}

Angka konsumsi ikan merupakan tingkat konsumsi masyarakat Indonesia terhadap komoditas ikan yang dikonversi dalam satuan $\mathrm{kg} / \mathrm{kap} / \mathrm{tahun}$. Dalam melakukan analisis angka konsumsi pada periode waktu tertentu. Secara ideal, penyediaan konsumsi ikan harus selalu lebih besar dibandingkan dengan capaian angka konsumsi ikan dengan selisih yang tidak terlalu lebar serta mempunyai trend yang selalu naik dari tahun ke tahun.

\section{METODOLOGI PENELITIAN}

\section{A. Sumber Data}

Data yang digunakan merupakan data sekuner yang didapatkan dari Dinas Kelautan dan Perikanan Provinsi Jawa Timur yang meliputi data tingkat konsumsi ikan, produksi perikanan tangkap, dan produksi perikanan budidaya. Data pengeluaran per kapita, rata-rata lama sekolah dan presentase penduduk miskin diperoleh dari data publikasi BPS dengan uni penelitian sebanyak 38 Kabupaten/Kota di Jawa Timur tahun 2016. Variabel penelitian digunakan pada penelitian kali ini disajikan pada Tabel 2.

Tabel 2.

Variable Penelitian

\begin{tabular}{|c|c|}
\hline Variable & Nama Variabel \\
\hline $\mathrm{Y}$ & Tingkat Konsumsi Ikan \\
\hline $\mathrm{X}_{1}$ & Produksi Perikanan Tangkap \\
\hline $\mathrm{X}_{2}$ & Produksi Perikanan Budidaya \\
\hline $\mathrm{X}_{3}$ & Pengeluaran Per Kapita \\
\hline $\mathrm{X}_{4}$ & Rata-rata Lama Sekolah \\
\hline $\mathrm{X}_{5}$ & Presentase Penduduk Miskin \\
\hline$X_{6}$ & $\begin{array}{l}\text { Wilayah }= \\
0: \text { tidak punya pantai } \\
1: \text { punya pantai }\end{array}$ \\
\hline
\end{tabular}

Penggunaan variabel didasari oleh penelitian sebelumnya dan dari dinas kelautan dan perikanan untuk variabel produksi perikanan tangkap dan produksi perikanan budidaya merujuk pada dinas kelautan dan perikanan yang menyatakan bahwa tingkat konsumsi ikan dipengaruhi oleh produksi perikanan sementara untuk variabel pengeluaran per kapita dan rata-rata lama sekolah dari penelitian sebelumnya [2]. Dan untuk variabel presentase penduduk miskin dari penelitian yang dilakukan oleh Nurjanah dkk [5]. Struktur data dari variabel respon dan variabel prediktor yang digunakan dalam penelitian ini secara terperinci disajikan dalam Tabel 3.
Tabel 3.

Variable Penelitian

\begin{tabular}{ccccc}
\hline $\begin{array}{c}\text { Kabupaten/ } \\
\text { Kota }\end{array}$ & $\mathrm{Y}$ & $\mathrm{X}_{1}$ & $\cdots$ & $\mathrm{X}_{6}$ \\
\hline 1 & $\mathrm{Y}_{1}$ & $\mathrm{X}_{1(1)}$ & $\cdots$ & $\mathrm{X}_{6(1)}$ \\
2 & $\mathrm{Y}_{2}$ & $\mathrm{X}_{1(2)}$ & $\cdots$ & $\mathrm{X}_{6(2)}$ \\
3 & $\mathrm{Y}_{3}$ & $\mathrm{X}_{1(3)}$ & $\cdots$ & $\mathrm{X}_{6(3)}$ \\
4 & $\mathrm{Y}_{4}$ & $\mathrm{X}_{1(4)}$ & $\cdots$ & $\mathrm{X}_{6(4)}$ \\
$\vdots$ & $\vdots$ & $\vdots$ & $\cdots$ & $\vdots$ \\
38 & $\mathrm{Y}_{38}$ & $\mathrm{X}_{1(38)}$ & $\cdots$ & $\mathrm{X}_{6(38)}$ \\
\hline \hline
\end{tabular}

\section{B. Langkah Analisis}

Langkah analisis yang digunakan dalam penelitian ini adalah sebagai berikut,

1. Melakukan analisis deskriptif untuk variabel respon dan variabel prediktor disajikan dalam bentuk tabel-tabel dan diagram-diagram.

2. Membentuk scatterplot antara variabel respon dengan masing-masing variabel prediktor yang digunakan sebagai deteksi awal pola hubungan antar variabel tersebut.

3. Memodelkan data menggunakan pendekatan regresi nonparametrik spline dengan menggunakan satu, dua, tiga, dan kombinasi knot.

4. Menetapkan model terbaik yang mempunyai nilai GCV minimum

5. Membuat model regresi nonparametrik spline dengan titik knot optimal

6. Melakukan pengujian signifikansi parameter secara serentak dan individu pada model regresi nonparametrik spline terbaik

7. Melakukan pemeriksaan asumsi terhadap residual dari model regresi nonparametrik spline yang terbentuk

8. Menarik kesimpulan

\section{ANALISIS DAN PEMBAHASAN}

\section{A. Deskriptif Tingkat Konsumsi Ikan dan Faktor-faktor yang Diduga Mempengaruhi}

Tabel 4 menunjukkan bahwa variabel respon memiliki nilai mean dan varians sebesar 30,34 dan 79,06, tingkat konsumsi ikan terendah mencapai angka 17,05 di Kabupaten Ponorogo sementara untuk terbesar mencapai 53,71 di Kabuapten Sumenep. Untuk variabel produksi perikanan tangkap di Jawa Timur memiliki nilai terkecil sebesar 0 ton di Kota Batu, Kota Blitar, dan Kota Malang dan produksi terbesar mencapai angka 73246 ton di Kabupaten Lamongan. Variabel produksi perikanan budidaya memiliki nilai terkecil sebesar 62 ton di Kota Batu dan nilai tertinggi mencapai angka 626589 di Kabupaten Sumenep. Karakteristik variabel pengeluaran per kapita memiliki nilai terkecil mencapai 54,78 di Kota Probolinggo serta nilai tertinggi mencapai nilai 69,5 di Kabupaten Sumenep. Variabel rata-rata lama sekolah memiliki nilai terendah mencapai 3,79 di Kabupaten Sampang dan nilai tertinggi mencapai 11,09 di Kota Madiun serta variabel presentase penduduk miskin memiliki nilai terendah mencapai 4,33 di Kota Malang dan nilai tertinggi mencapai 24,11 di Kabupaten Sampang 
Tabel 4.

Statistika Deskriptif Variabel

\begin{tabular}{crrrr}
\hline \hline Variable & Rata-Rata & Minimum & Maximum & \multicolumn{1}{c}{ Varians } \\
\hline $\mathrm{Y}$ & 30,34 & 17,05 & 53,71 & 79,06 \\
$\mathrm{X}_{1}$ & 10732 & 0 & 73246 & 276747374 \\
$\mathrm{X}_{2}$ & 30594 & 62 & 626589 & 104776100 \\
$\mathrm{X}_{3}$ & 62,305 & 54,78 & 69,5 & 12,781 \\
$\mathrm{X}_{4}$ & 7,47 & 3,79 & 11,09 & 2,905 \\
$\mathrm{X}_{5}$ & 11,875 & 4,33 & 24,11 & 23,372 \\
\hline \hline
\end{tabular}

Uji multikolinieritas menggunakan nilai VIF untuk masingmasing variabel prediktor yang digunakan ditunjukkan pada Tabel 5 .

Tabel 5.

Nilai VIF Variabel Prediktor

\begin{tabular}{cc}
\hline \hline Variabel & VIF \\
\hline $\mathrm{X}_{1}$ & 1,741 \\
$\mathrm{X}_{2}$ & 1,392 \\
$\mathrm{X}_{3}$ & 3,064 \\
$\mathrm{X}_{4}$ & 5,176 \\
$\mathrm{X}_{5}$ & 3,866 \\
$\mathrm{X}_{6}$ & 1,529 \\
\hline \hline
\end{tabular}

Tabel 5 menunjukkan bahwa nilai VIF masing-masing variabel prediktor kurang dari 10. Hal itu mengindikasikan bahwa tidak ada multikolinieritas antara variabel prediktor

\section{B. Pemodelan Tingkat Konsumsi Ikan}

Sebelum melakukan pemodelan terlebih dahulu menggunakan regresi nonparametrik spline dilakukan identifikasi pola hubungan antar variabel respon dan variabel prediktor dengan dilihat secara visual menggunakan scatterplot. Gambar 1 menunjukkan pola hubungan antara variabel respon yakni tingkat konsumsi ikan dengan semua variabel prediktor antara lain produksi perikanan tangkap, produksi perikanan budidaya, pengeluaran per kapita, rata-rata lama sekolah dan presentase penduduk miskin. Didapatkan pola hubungan yang terbentuk ada kecenderungan bahwa kelima pola data tidak ada yang membentuk suatu pola linier terte-ntu. Untuk menjelaskan sccatterplot tingkat konsumsi ikan ter-hadap faktor-faktor yang diduga mempengaruhi bahwa garis li-nier tidak satu garis lurus maka diperlukan knot dan dengan demikian, dalam pemodelan regresi digunakan pendekatan regresi nonparametrik.

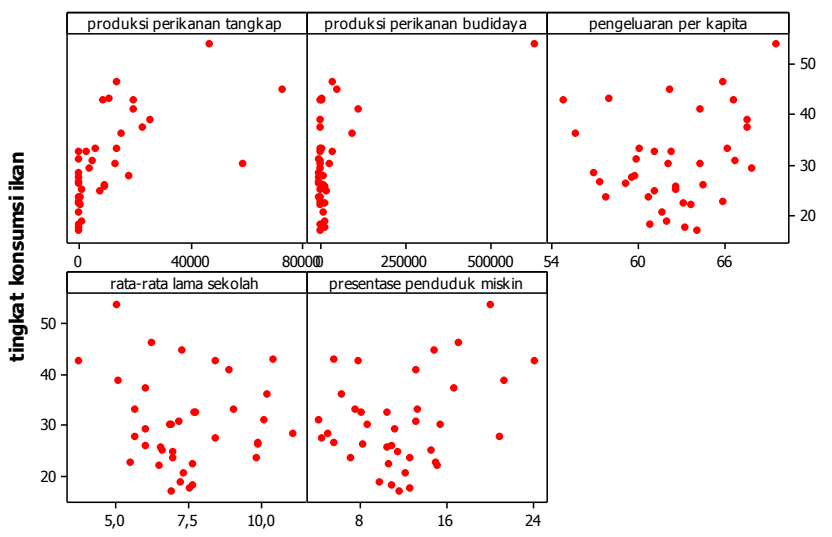

Gambar 1. Scatterplot antara variabel respon dan prediktor.

\section{Pemilihan Titik Knot Optimum}

Titik knot optimal diperoleh dari nilai GCV yang paling minimum. Titik knot yang digunakan dalam penelitian ini dibatasi pada satu titik knot, dua titik knot, tiga titik knot, dan kombinasi knot.

Tabel 6.

Nilai GCV dengan Satu Knot

\begin{tabular}{ccccccc}
\hline \hline $\mathrm{X}_{1}$ & $\mathrm{X}_{2}$ & $\mathrm{X}_{3}$ & $\mathrm{X}_{4}$ & $\mathrm{X}_{5}$ & MSE & \multirow{2}{*}{$\mathrm{GCV}$} \\
\hline 16443,05 & 140710,6 & 58,1 & 5,43 & 8,74 & 20,61 & 33,06 \\
17937,87 & 153496,9 & 58,4 & 5,58 & 9,14 & 20,59 & 33,04 \\
$\mathbf{1 9 4 3 2 , 6 9}$ & $\mathbf{1 6 6 2 8 3 , 2}$ & $\mathbf{5 8 , 7}$ & $\mathbf{5 , 7 3}$ & $\mathbf{9 , 5 5}$ & $\mathbf{2 0 , 4 2}$ & $\mathbf{3 2 , 7 6}$ \\
20927,51 & 179069,4 & 59 & 5,88 & 9,95 & 20,53 & 32,94 \\
22422,34 & 191855,7 & 59,3 & 6,04 & 10,36 & 20,89 & 33,48 \\
\hline \hline
\end{tabular}

$\mathrm{K}_{1}=19432,69 \quad \mathrm{~K}_{3}=58,7 \quad \mathrm{~K}_{5}=9,55$

$\mathrm{K}_{2}=166283,2 \quad \mathrm{~K}_{4}=5,73$

Artinya nilai GCV yang minimum dengan satu knot terdapat titik knot pada setiap variabel prediktor, untuk variabel produksi perikanan tangkap dihasilkan titik knot pada nilai 19432,69, variabel produksi peerikanan budidaya pada nilai 166283,2 , variabel pengeluaran per kapita diperoleh nilai 58,7, variabel rata-rata lama sekolah terdapat pada nilai 5,73, dan variabel presentase penduduk miskin didapatkan pada titik 9,55 .

Selanjutnya, dilakukan dengan cara serupa untuk mengetahui nilai GCV minimum untuk dua dan tiga knot. hasil nilai GCV dengan dua titik knot dengan model yang dihasilkan sebagai berikut.

Tabel 7.

Nilai GCV dengan Dua Knot

\begin{tabular}{ccccrcc}
\hline \hline $\mathrm{X}_{1}$ & $\mathrm{X}_{2}$ & $\mathrm{X}_{3}$ & $\mathrm{X}_{4}$ & \multicolumn{1}{c}{$\mathrm{X}_{5}$} & MSE & $\mathrm{GCV}$ \\
\hline 20927,51 & 179069,4 & 59,00 & 5,89 & 9,96 & \multirow{2}{*}{16,25} & \multirow{2}{*}{27,91} \\
32886,09 & 281359,7 & 61,40 & 7,08 & 13,19 & & \\
$\mathbf{2 0 9 2 7 , 5 1}$ & $\mathbf{1 7 9 0 6 9 , 4}$ & $\mathbf{5 9 , 0 0}$ & $\mathbf{5 , 8 9}$ & $\mathbf{9 , 9 6}$ & $\mathbf{1 6 , 2 2}$ & $\mathbf{2 7 , 8 5}$ \\
$\mathbf{3 4 3 8 0 , 9 2}$ & $\mathbf{2 9 4 1 4 5 , 9}$ & $\mathbf{6 1 , 7 0}$ & $\mathbf{7 , 2 3}$ & $\mathbf{1 3 , 5 9}$ & & \\
20927,51 & 179069,4 & 59,00 & 5,89 & 9,96 & \multirow{2}{*}{16,25} & 27,90 \\
35875,74 & 306932,2 & 62,00 & 7,38 & 14,00 & & \\
\hline \hline
\end{tabular}

$\left(\mathrm{K}_{1}=20927,51 \quad ; \mathrm{K}_{2}=34380,92 ; \mathrm{K}_{3}=1790069,44\right)$,

$\left(\mathrm{K}_{4}=2941145,98 ; \mathrm{K}_{5}=59 \quad ; \mathrm{K}_{6}=61,7\right)$,

$\left(\mathrm{K}_{7}=5,89 \quad ; \mathrm{K}_{8}=7,23 ; \mathrm{K}_{9}=9,96 \quad ; \mathrm{K}_{10}=13,59\right)$,

Artinya nilai GCV yang minimum dengan dua knot terdapat titik knot pada setiap variabel prediktor, untuk variabel produksi perikanan tangkap dihasilkan titik knot pada nilai 20927,5 dan nilai 34380,9, variabel produksi perikanan budidaya pada nilai 179069,4 dan nilai 294145,9 , variabel pengeluaran per kapita diperoleh nilai 59 dan nilai 61,7 , variabel rata-rata lama sekolah terdapat pada nilai 5,89 dan nilai 7,23, sementara untuk variabel presentase penduduk miskin didapatkan pada nilai 9,96 dan nilai 13,59 .

Tabel 8.

Nilai GCV dengan Tiga Knot

\begin{tabular}{rrccrcr}
\hline \hline \multicolumn{1}{c}{$\mathrm{X}_{1}$} & \multicolumn{1}{c}{$\mathrm{X}_{2}$} & $\mathrm{X}_{3}$ & $\mathrm{X}_{4}$ & \multicolumn{1}{c}{$\mathrm{X}_{5}$} & MSE & GCV \\
\hline 2989,64 & 25634,1 & 55,40 & 4,10 & 5,11 & & \\
4484,47 & 38420,4 & 55,70 & 4,25 & 5,51 & 11,87 & 25,35 \\
26906,80 & 230214,5 & 60,20 & 6,48 & 11,57 & & \\
$\mathbf{2 9 8 9 , 6 4}$ & $\mathbf{2 5 6 3 4 , 1}$ & $\mathbf{5 5 , 4 0}$ & $\mathbf{4 , 1 0}$ & $\mathbf{5 , 1 1}$ & & \\
$\mathbf{4 4 8 4 , 4 7}$ & $\mathbf{3 8 4 2 0 , 3}$ & $\mathbf{5 5 , 7 0}$ & $\mathbf{4 , 2 5}$ & $\mathbf{5 , 5 1}$ & $\mathbf{1 1 , 7 9}$ & $\mathbf{2 5 , 1 9}$ \\
$\mathbf{2 8 4 0 1 , 6 3}$ & $\mathbf{2 4 3 0 0 0 , 8}$ & $\mathbf{6 0 , 5 0}$ & $\mathbf{6 , 6 3}$ & $\mathbf{1 1 , 9 8}$ & & \\
2989,64 & 25634,1 & 55,40 & 4,10 & 5,11 & & \\
4484,47 & 38420,3 & 55,70 & 4,25 & 5,51 & 11,84 & 25,28 \\
29896,45 & 255787,1 & 60,80 & 6,78 & 12,38 & & \\
\hline \hline
\end{tabular}


$\left(\mathrm{K}_{1}=2989,64 ; \quad \mathrm{K}_{2}=4484,47 ; \quad \mathrm{K}_{3}=28401,63\right), \quad\left(\mathrm{K}_{4}=\right.$ 25634,$\left.06 ; \quad \mathrm{K}_{5}=38420,34 ; \quad \mathrm{K}_{6}=243000,85\right)$,

$\left(\mathrm{K}_{7}=55,4 ; \mathrm{K}_{8}=55,7 ; \mathrm{K}_{9}=60,50 ; \quad \mathrm{K}_{10}=4,1\right)$,

$\left(\mathrm{K}_{11}=4,25 ; \mathrm{K}_{12}=6,63 ; \mathrm{K}_{13}=5,11 ; \mathrm{K}_{14}=5,51 ; \mathrm{K}_{15}=11,98\right)$, Artinya nilai GCV yang minimum dengan tiga knot terdapat titik knot pada setiap variabel prediktor, untuk variabel produksi perikanan tangkap dihasilkan titik knot pada nilai 2989,5; nilai 4484,4 dan nilai 28401,6 , variabel produksi perikanan budidaya pada nilai 25634,1 ; nilai 38420,3 dan nilai 243000,8 , variabel pengeluaran per kapita diperoleh nilai 55,4; nilai 55,7 dan nilai 60,5 , variabel rata-rata lama sekolah terdapat pada nilai 4,1 ; nilai 4,25 dan nilai 6,63 , sementara untuk variabel presentase penduduk miskin didapatkan pada nilai 5,11 ; nilai 5,51 dan nilai 11,98 .

Kombinasi knot adalah kombinasi dari satu, dua, dan tiga titik knot dikombinasikan. Proses yang dilakukan untuk memilih nilai GCV minimum, didapatkan hasil GCV minimum disajikan dalam Tabel 9.

Tabel 9.

Nilai GCV dengan Kombinasi Knot

\begin{tabular}{crrrrrr}
\hline \hline $\mathrm{X}_{1}$ & \multicolumn{1}{c}{$\mathrm{X}_{2}$} & \multicolumn{1}{c}{$\mathrm{X}_{3}$} & $\mathrm{X}_{4}$ & \multicolumn{1}{c}{$\mathrm{X}_{5}$} & $\mathrm{MSE}$ & $\mathrm{GCV}$ \\
\hline 20927,51 & 25634,06 & 55,4 & 5,73 & 9,55 & & \\
34380,92 & 38420,34 & 55,7 & & & 75,30 & 34,86 \\
& 243000,9 & 60,5 & & & & \\
$\mathbf{2 0 9 2 7 , 5 1}$ & $\mathbf{2 5 6 3 4 , 0 6}$ & $\mathbf{5 5 , 4}$ & $\mathbf{5 , 7 3}$ & $\mathbf{9 , 9 5}$ & & \\
$\mathbf{3 4 3 8 0 , 9 2}$ & $\mathbf{3 8 4 2 0 , 3 4}$ & $\mathbf{5 5 , 7}$ & & $\mathbf{1 3 , 5 9}$ & $\mathbf{8 5 , 5 9}$ & $\mathbf{2 1 , 9 8}$ \\
& $\mathbf{2 3 0 0 0 , 9}$ & $\mathbf{6 0 , 5}$ & & & & \\
20927,51 & 25634,06 & 55,4 & 5,73 & 5,10 & & \\
34380,92 & 38420,34 & 55,7 & & 5,51 & 75,47 & 34,55 \\
& 243000,9 & 60,6 & & 11,97 & & \\
\hline \hline
\end{tabular}

Kombinasi knot yang terbentuk adalah $(2,3,3,1,2)$ dengan titik knot optimum untuk masing-masing variabel diperoleh hasil knot sebagai berikut.

$\left(\mathrm{K}_{1}=20927,51 ; \mathrm{K}_{2}=34380,92\right)$,

$\left(\mathrm{K}_{3}=25634,06 ; \mathrm{K}_{4}=38420,38 ; \mathrm{K}_{5}=23000,9\right)$,

$\left(\mathrm{K}_{6}=55,4 ; \mathrm{K}_{7}=55,7 ; \mathrm{K}_{8}=60,5\right),\left(\mathrm{K}_{9}=5,73674\right)$,

$\left(\mathrm{K}_{10}=9,957 ; \mathrm{K}_{11}=13,593\right)$.

Artinya nilai GCV yang minimum dengan kombinasi knot terdapat titik knot pada setiap variabel prediktor, untuk variabel produksi perikanan tangkap dihasilkan titik knot pada nilai 20927,5; dan nilai 34380,9, variabel produksi perikanan budidaya pada nilai 25634,06; nilai 38420,3 dan nilai 23000,9, variabel pengeluaran per kapita diperoleh nilai 55,4; nilai 55,7 dan nilai 60,5, variabel rata-rata lama sekolah terdapat pada nilai 5,73, sementara untuk variabel presentase penduduk miskin didapatkan pada nilai 9,95 dan nilai 13,59.

\section{Pemilihan Model Terbaik}

Model regresi nonparametrik spline terbaik adalah model dengan nilai GCV paling minimum. Perbandingan nilai GCV paling minimum dan banyak parameter dari satu titik knot, dua, tiga dan kombinasi knot disajikan pada Tabel 8 .

Tabel 10.

.Nilai GCV Minimum

\begin{tabular}{ccc}
\multicolumn{3}{c}{.Nilai GCV Minimum } \\
\hline \hline Jumlah knot & GCV Minimum & Banyak Parameter \\
\hline 1 titik knot & 32,766 & 12 \\
2 titik knot & 27,85 & 17 \\
3 titik knot & 25,19 & 22 \\
Kombinasi knot & 21,98 & 18 \\
$(2,3,3,1,2)$ & \\
\hline \hline
\end{tabular}

Nilai GCV minimum dimiliki oleh kombinasi knot $(2,3,3,1,2)$, sehingga knot yang digunakan sebagai model terbaik adalah kombinasi knot dengan model sebagai berikut.

$\hat{y}_{i}=0,003764+0,000813 x_{1}-0,00273\left(x_{1}-20927,51\right)_{+}+0,00257\left(x_{1}-34380,92\right)_{+}$

$$
\begin{aligned}
& -0,00015 x_{2}+0,00115\left(x_{2}-25634,06\right)_{+}-0,00117\left(x_{2}-38420,38\right)_{+} \\
& +0,00029\left(x_{2}-23000,9\right)_{+}+0,3802 x_{3}+0,1258\left(x_{3}-55,4\right)_{+}+0,1026\left(x_{3}-55,7\right)_{+} \\
& +0,6963\left(x_{3}-60,5\right)_{+}+0,835 x_{4}+1,109\left(x_{4}-5,736\right)_{+}-1,166 x_{5}+0,707\left(x_{5}-9,957\right)_{+} \\
& +1,326\left(x_{5}-13,59\right)_{+}-0,136 D
\end{aligned}
$$

\section{Pengujian Signifikansi Parameter}

Hipotesis dari uji serentak sebagai berikut.

$\mathrm{H}_{0}: \beta_{1}=\beta_{2}=\ldots=\beta_{17}=0$

$\mathrm{H}_{1}$ : minimal ada satu $\beta_{j} \neq 0, j=1,2, \ldots, 17$

Tabel 11.

Uji Signifikansi Parsial secara Multivaariat

\begin{tabular}{cccccc}
\hline \hline $\begin{array}{c}\text { Sumber } \\
\text { variansi }\end{array}$ & $\mathrm{Db}$ & $\mathrm{SS}$ & $\mathrm{MS}$ & $\mathrm{F}_{\text {hitung }}$ & P-value \\
\hline Regresi & 17 & 2505,08 & 147,35 & 7,0009 & $3,925 \times 10^{-5}$ \\
Residual & 20 & 420,96 & 21,04 & & \\
Total & 37 & 2926,05 & & & \\
\hline \hline
\end{tabular}

Tabel 11 menunjukkan $F_{\text {hitung }}$ yang dihasilkan 7,0009 dimana lebih besar dari $\mathrm{F}_{\text {tabel }}$ yaitu 2,23 sehingga keputusan tolak $\mathrm{H}_{0}$ yang artinya minimal ada satu parameter yang berpengaruh signifikan terhadap model.

Digunakan untuk mengetahui signifikansi dari masingmasing variabel prediktor secara individu dengan menggunakan uji t. Hipotesis yang digunakan adalah sebagai berikut.

$\mathrm{H}_{0}: \beta_{j}=0, j=1,2, \ldots, 17$

$\mathrm{H}_{1}: \beta_{j} \neq 0, j=1,2, \ldots, 17$

Tabel 12 menunjukkan bahwa 13 dari 17 parameter adalah signifikan, meski terdapat parameter yang tak signifikan, lima variabel yang digunakan dianggap signifikan karena minimal dalam satu variabel terdapat satu parameter yang signifikan.

Tabel 12.

Uji Parameter Secara Parsial

\begin{tabular}{ccccc}
\hline \hline Variabel & Parameter & Koefisien & $\mathrm{T}_{\text {hitung }}$ & Keputusan \\
\hline \hline Intercept & $\beta_{0}$ & 0,00376 & 1,321 & Gagal Tolak $\mathrm{H}_{0}$ \\
\hline$X_{1}$ & $\beta_{3}$ & 0,00081 & 5,444 & Tolak $\mathrm{H}_{0}$ \\
& $\beta_{2}$ & $-0,00273$ & $-2,860$ & Tolak $\mathrm{H}_{0}$ \\
& $\beta_{3}$ & 0,00257 & 2,083 & Gagal Tolak $\mathrm{H}_{0}$ \\
& $\beta_{4}$ & $-0,00015$ & $-1,070$ & Gagal Tolak $\mathrm{H}_{0}$ \\
$X_{2}$ & $\beta_{5}$ & 0,00115 & 2,270 & Tolak $\mathrm{H}_{0}$ \\
& $\beta_{6}$ & $-0,00116$ & $-2,592$ & Tolak $\mathrm{H}_{0}$ \\
& $\beta_{7}$ & 0,00029 & 2,535 & Tolak $\mathrm{H}_{0}$ \\
& $\beta_{8}$ & 0,38021 & 13,18 & Tolak $\mathrm{H}_{0}$ \\
$X_{3}$ & $\beta_{9}$ & 0,12583 & 0,941 & Gagal Tolak $\mathrm{H}_{0}$ \\
& $\beta_{10}$ & 0,1026 & 0,784 & Gagal Tolak $\mathrm{H}_{0}$ \\
& $\beta_{11}$ & 0,69633 & 2,946 & Tolak $\mathrm{H}_{0}$ \\
$X_{4}$ & $\beta_{12}$ & 0,83563 & 4,471 & Tolak $\mathrm{H}_{0}$ \\
& $\beta_{13}$ & 1,10969 & 4,065 & Tolak $\mathrm{H}_{0}$ \\
$X_{5}$ & $\beta_{14}$ & $-1,16621$ & $-3,533$ & Tolak $\mathrm{H}_{0}$ \\
& $\beta_{15}$ & 0,70723 & 3,215 & Tolak $\mathrm{H}_{0}$ \\
$D_{1}$ & $\beta_{16}$ & 1,32639 & 3,698 & Tolak $\mathrm{H}_{0}$ \\
& $\beta_{17}$ & $-0,13578$ & $-3,278$ & Tolak $\mathrm{H}_{0}$ \\
\hline \hline
\end{tabular}


Pengujian dan Pemeriksaan Asumsi Residual

Pengujian Asumsi Residual Identik

$$
\begin{aligned}
& \mathrm{H}_{0}: \beta_{1}=\beta_{2}=\ldots=\beta_{17}=0 \\
& \mathrm{H}_{1}: \text { minimal ada satu } \beta_{j} \neq 0, j=1,2, \ldots, 17
\end{aligned}
$$

Tabel 13

ANOVA Uji Glejser

\begin{tabular}{cccccc}
\hline \hline $\begin{array}{c}\text { Sumber } \\
\text { variansi }\end{array}$ & $\mathrm{Db}$ & $\mathrm{SS}$ & $\mathrm{MS}$ & $\mathrm{F}_{\text {hitung }}$ & P-value \\
\hline Regresi & 17 & 64,045 & 3,767 & 0,6311 & 0,829 \\
Residual & 20 & 119,38 & 5,969 & & \\
Total & 37 & 183,42 & & & \\
\hline \hline
\end{tabular}

dari Tabel 13 dapat diambil keputusan gagal tolak $\mathrm{H}_{0}$ karena nilai P-value lebih besar dari pada nilai alpha $(0,05)$ sehingga tidak terjadi kasus heteroskedastisitas atau asumsi residual identik telah terpenuhi. Selanjutnya Pemeriksaan Asumsi Residual Independen

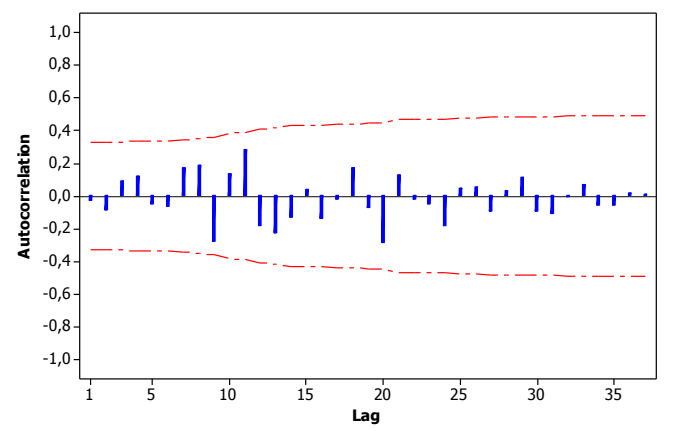

Gambar 2. Plot ACF Residual.

Pemeriksaan residual independen dilakukan dengan menggunakan inerval konfidensi ACF. Pada Gambar 2 menunjukkan bahwa tidak terlihat adanya autokorelasi (ACF) yang signifikan atau keluar dari batas atas dan bawah. Bahwa asumsi residual independen telah terpenuhi.

Pengujian Asumsi Residual Berdistribusi Normal dengan hipotesis sebagai berikut

$\mathrm{H}_{0}: F(x)=F_{0}(x)$ (residual berdistribusi normal)

$\mathrm{H}_{1}: F(x) \neq F_{0}(x)$ (residual tidak berdistribusi normal)

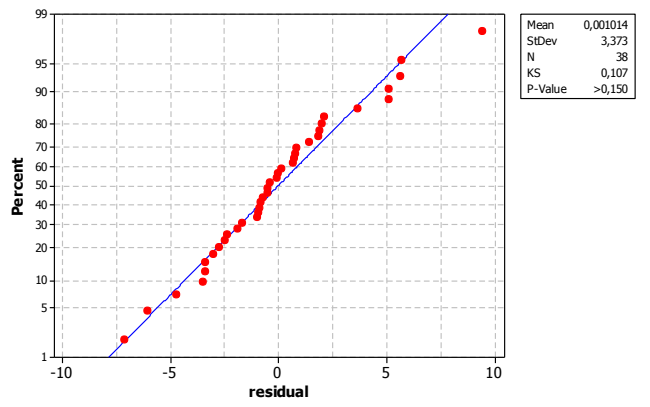

Gambar 3. Probability Plot dengan Kolmogorov Smirnov.

dari Gambar 3 dapat diperoleh nilai P-value $>0,15$ yang memiliki nilai lebih besar dari 0,05 sehingga dapat disimpulkan residual mengikuti distribusi normal atau asumsi residual normal telah terpenuhi

\section{Koefisien Determinasi}

Perhitungan $\mathrm{R}^{2}$ didapatkan sebagai berikut.

$$
\begin{aligned}
R^{2} & =\frac{S S R}{S S T} \times 100 \% & R^{2}-A d j & =1-\frac{M S E}{M S T} \times 100 \% \\
& =85,61 \% & & =73,38 \%
\end{aligned}
$$

Model regresi nonparametrik spline linier dengan kombinasi knot menghasilkan nilai $\mathrm{R}^{2}$ sebesar $85,61 \%$ artinya bahwa variabel prediktor yang diguanakan mampu menjelaskan model sebesar $85,61 \%$ sisanya $14,39 \%$ dijelaskan oleh variabel lain yang tidak masuk dalam model. Sedangkan $R^{2}$-Adj memiliki nilai sebesar $73,38 \%$ artinya variabel prediktor yang digunakan mampu menjelaskan model sebesar $73,38 \%$ sisanya $26,62 \%$ dijelaskan oleh variabel lain yang tidak masuk dalam model.

\section{Interpretasi Model}

Setelah dilakukan pengujian asumsi residual terpenuhi dan diperoleh model regresi nonparametrik spline diinterpretasikan salah satu variabel prediktor yaitu variabel produksi perikanan tangkap sebagai berikut.

$$
\begin{aligned}
& \hat{y}=0,000813 x_{1}-0,00273\left(x_{1}-20927,51\right)_{+}+0,00257\left(x_{1}-34380,92\right)_{+} \\
& 0,000813 x_{1} \quad ; x_{1}<20927,51 \\
& =\left\{\begin{array}{c}
-0.001917 x_{1}+57,132 \quad ; 20927,51 \leq x_{1}<34380,92 \\
0,000653 x_{1}-31,22 \quad ; x_{1} \geq 34380,92
\end{array}\right.
\end{aligned}
$$

Pada model tersebut dapat diinterpretasikan dengan visualisasi peta sebagai berikut

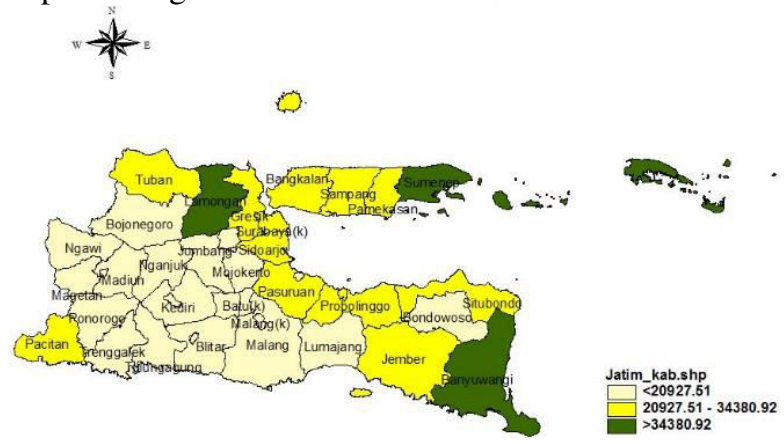

Gambar 4. Visualisasi Peta untuk Variabel Produksi Perikanan Tangkap.

a.Hasil Gambar 4. Menunjukkan wilayah Kab. Bojonegoro, Kab. Ngawi, Kab. Magetan, Kab. Ponorogo, Kota Malang, Kota Batu, Kab. Bondowoso, Kab. Kediri, Kota Kediri, Kab. Madiun, Kota Madiun, Kab. Nganjuk, Kab. Mojokerto, Kota Mojokerto, Kab. Jombang dan Kota Blitar termasuk daerah yang memiliki nilai produksi perikanan tangkap kurang dari 20927,51 ton. Jika daerah tersebut menghasilkan produksi per-ikanan tangkap naik sebesari 1 ton akan menyebabkan nilai tingkat konsumsi ikan di daerah tersebut cenderung naik sebe-sar 0,000813 kg/kap/thn.

b. Kab. Pacitan, Kab. Jember, Kab. Situbondo, Kab. Probolinggo, Kota Probolinggo, Kab. Pasuruan, Kab. Sidoarjo, Kota Surabaya, Kab. Gresik, Kab. Tuban, Kab. Bangkalan, Kab. Sampang, dan Kab. Pamekasan merupakan daerah yang memiliki nilai produksi perikanan tangkap antara 20927,51 hingga 34380,92 ton. Jika daerah tersebut menghasilkan produksi perikanan tangkap naik sebesar 1 ton maka akan me- 
nyebabkan nilai tingkat konsumsi ikan cenderung turun sebesar 0,00192 kg/kap/thn dikarenakan dari hasil perikanan tangkap tersebut kebanyakan ikan untuk di ekspor ke luar negeri antara lain peng-hasil ikan kakap merah, kakap putih, dan tengiri. Akibatnya penduduk didaerah tersebut kebanyakan sulit untuk mendapat-kan ikan yang murah untuk dikonsumsi (Surya, 2018).

c.Sementara untuk Kab. Banyuwangi, Kab. Sumenep dan Kab. Lamongan merupakan daerah memiliki produksi perikanan tangkap lebih dari 34380,92 ton. Jika daerah tersebut menghasilkan produksi perikanan tangkap naik sebesar 1 ton akan menyebabkan nilai tingkat konsumsi ikan cenderung naik sebesar $0,000653 \mathrm{~kg} / \mathrm{kap} / \mathrm{thn}$.. Dan utnuk variabel prediktor yang lainnya diinter-pretasikan sama dengan interpretasi variabel prediktor produk-si perikanan tangkap

\section{KESIMPULAN DAN SARAN}

\section{A. Kesimpulan}

Berdasarkan hasil analisis yang telah dijelaskan maka diperoleh kesimpulan bahwa rata-rata tingkat konsumsi ikan di Jawa Timur tergolong rendah yaitu sebesar 30,34 yang tersebar di 38 Kabupaten/Kota di Jawa Timur. Daerah yang memiliki nilai tingkat konsumsi ikan tertinggi berada di Kabupaten Sumenep dan untuk Kabupaten Ponorogo menjadi daerah yang memiliki nilai tingkat konsumsi ikan yang terendah pada tahun 2016.

Selain itu, dengan analisis regresi nonparametrik spline didapatkan model tingkat konsumsi ikan terbaik dari titik knot yang paling optimum yaitu menggunakan kombinasi knot dengan semua variabel prediktor berpengaruh signifikan dan dengan nilai koefisien determinasi sebesar $85,61 \%$ dan nilai $R^{2}$-adj sebesar $73,38 \%$ sehingga diperoleh model.

$$
\begin{aligned}
\hat{y}_{i} & =0,003764+0,000813 x_{1}-0,00273\left(x_{1}-20927,51\right)_{+}+0,00257\left(x_{1}-34380,92\right)_{+} \\
& -0,00015 x_{2}+0,00115\left(x_{2}-25634,06\right)_{+}-0,00117\left(x_{2}-38420,38\right)_{+} \\
& +0,00029\left(x_{2}-23000,9\right)_{+}+0,3802 x_{3}+0,1258\left(x_{3}-55,4\right)_{+}+0,1026\left(x_{3}-55,7\right)_{+} \\
& +0,6963\left(x_{3}-60,5\right)_{+}+0,835 x_{4}+1,109\left(x_{4}-5,736\right)_{+}-1,166 x_{5}+0,707\left(x_{5}-9,957\right)_{+} \\
& +1,326\left(x_{5}-13,59\right)_{+}-0,136 D
\end{aligned}
$$

\section{B. Saran}

Saran yang dapat disampaikan dalam penelitian ini adalah untuk pemerintah dan dinas kelautan dan perikanan Provinsi Jawa Timur adalah melakukan penyuluhan dan sosialisasi secara berkala untuk daerah-daerah yang memiliki tingkat konsumsi ikan yang masih rendah. Melakukan penguatan dari segi faktor-faktor yang memberikan pengaruh signifikan terhadap tingkat konsumsi ikan yang masih rendah untuk setiap wilyah.

\section{DAFTAR PUSTAKA}

[1] Eubank, Nonparametric Regresion and Spline Smoothing. New York: Marcel Dekker Inc, 1999.

[2] Y. Hartati, "Faktor-faktor yang Berhubungan Dengan Konsumsi Ikan dan Status Gizi Anak 1-2 Tahun Di Kecamatan Gandus Kota Palembang Tahun 2005," 2005.

[3] I. Budiantara, "Penelitian Bidang Regresi Spline Menuju Terwujudnya Penelitian Statistika yang Mandiri dan Berkarakter," in Makalah Pembicara Utama pada Seminar Nasional FMIPA, 2011.

[4] D. N.R and S. H., Analisis Regresi Terapan. Jakarta: Gramedia Pustaka Utama, 1992.

[5] T. Nurjanah, Hidayat and S. M. Perdana, "Analisis Faktor-faktor yang Mempengaruhi Konsumsi Ikan Pada Wanita Dewasa Di Indonesia," pp. 1-9, 2015. 